Page :750-758. ISBN: 978-602-6 988-75-1

Web Jurnal Online: jurnal.unmuhjember.ac.id

By: Zahratul Idami; Andriansyah

The Concept of Ethics in Leadership According to Imam Al-ghazali Thought

\title{
THE CONCEPT OF ETHICS IN LEADERSHIP ACCORDING TO IMAM AL-GHAZALI THOUGHT
}

\author{
${ }^{1 *}$ Zahratul Idami and ${ }^{2}$ Andriansyah \\ Department of Government Studies, Faculty of Social and Political Sciences, \\ Universitas Syiah Kuala, Banda Aceh, Indonesia; \\ *Corresponding author: zahratulidami_isa@unsyiah.ac.id and \\ andrian22@mhs.unsyiah.ac.id
}

\begin{abstract}
Ethics in Leadership are an evolving and important subject to research in the Islamic political studies. This is because ethics in leadership are one of the foundations that deciding the value of good or bad. Many Muslim scholars who have poured his idea to build the concept of ethics in leadership that gives the benefit and happiness in this world and hereafter. Imam al-Ghazali is one of the scholars who has written works on ethics in leadership. His idea of ethics in leadership is built on a solid foundation and has a typical Sufi moral. His Thoughts on ethics in leadership has become a reference and an important example for many leaders in the world until today. This research is library research with the research is a qualitative descriptive approach. The results showed that the concept of ethics in leadership by Imam al-Ghazali oriented to the impact of the soul in the pursuit of happiness in this world and hereafter. Ethics in the thinking of Imam al-Ghazali described as rational and religious science that should be combined in the leadership. The idea of ethics in leadership was not similar to the dominant secular ethics. The requirement to be a leader according to Imam al-Ghazali is focused on aspects of the character and integrity of a leader. The essence is, ethics in leadership should be the path to apply God's law in order to create balance in the world toward eternal happiness in the afterlife.
\end{abstract}

Keywords: Ethics, Leadership, Imam al-Ghazali, Political Sciences. 


\section{INTRODUCTION}

In the study of Islamic politics, the concept of ethics in leadership was classified as a very important topic. This is because the concept of ethics in leadership is one of the important conditions for the creation of a country that baldatun thayyibatun wa rabbun ghafur. Baldatun thayyibatun wa rabbun ghafur is the ideals country in Islamic politics. For this reason, thorough investigation of ethical leadership is always done in line with the passage of time.

Muslim Scholars have studied the subject of ethics in leadership for a long time. The names of Muslim scholars such as Imam al-Mawardi, al-Juwayni, Imam al-Ghazali, and Ibn Taymiyah have influenced the scientific arena of ethical leadership. By making the leadership of the Prophet Muhammad as a prime example, studies on leadership ethics established by the scholars. Leadership is an implication of the human need to live in a society which later evolved into a country. In this case, human beings can not live alone in society. They need a leader. In the phrase of Ibn Khaldun, the human nature is to having state (Fida, 2017, p. 19).

Imam al-Ghazali was one of the scholars who has the nickname "Hujjatul Islam" because of the greatness of his idea. His thoughts on ethics in leadership written in His book entitled Tibr al-Masbuk Nasihati al-Muluk. It's a magnum opus in the political sciences. His book has been translated into many languages and become an important research material to this day. al-Masbuk Nasihati al-Muluk contains counsel to the leaders (Hasib, 2017, p. 2).

Reviewing some thought Imam al-Ghazali on ethics in leadership in his day as an urgency can be used as an alternative solution for the resolution of problems that the government facing today. Buildings concept of ethics and leadership that have been written by Imam al-Ghazali is a very valuable scientific heritage. Reflecting the thinking of Imam al-Ghazali which has become the benchmark of many leaders in the world today, obviously adds to the urgency of this paper. In addition, we really needed construction of the concept of ethics in leadership that could be the cornerstone of sciences.

\section{RESEARCH METHOD}

This paper is used library research method which focuses on the topic of ethics in leadership by Imam al-Ghazali thought. The data used were collected from literature and selected according to relevance and authenticity. The research approach used is qualitative descriptive.

According to Strauss and Corbin, a qualitative research is a type of research that produces findings that can not be achieved using statistical procedures or other means of verification procedures. Inductive methods used in gathering a variety of separate but related data to be combined. Inductive method is a method of thinking which stems from the particular to the general things (Grace, 2009, p. 1). In this study, the authors used data analysis model of Miles and Huberman consisting of data reduction activity (data reduction), presentation of data (data display), and conclusion/verification (conclusion drawing/verification). 
Page :750-758. ISBN: 978-602-6 988-75-1

Web Jurnal Online: jurnal.unmuhjember.ac.id

By: Zahratul Idami; Andriansyah

The Concept of Ethics in Leadership According to Imam Al-ghazali Thought

\section{RESULTS AND DISCUSSION}

\section{The Concept of Ethics According to Imam Al-Ghazali Thoughts)}

Imam al-Ghazali in his works on politics and leadership, always implicit thoughts on ethics. So it builds the impression that the Imam al-Ghazali much emphasis about moral ethics in leadership and political ideas. In the thought of Imam al-Ghazali, Ethics became a standard reference in the implementation of leadership. Ethics clearly have its own indicator. These indicators form a value system should be implemented in leadership. Ethics in the thought of Imam al-Ghazali religious and mystical, not similar to the dominant secular ethics dealing with human well-being in the world (Quasem, 1988, p. 10).

Ethical nature of Imam al-Ghazali religious and mystical formed during the process of 'uzlahnya. He wrote in his book Al-Munqidz Min adh-Dhalal, "I know for sure that the Sufis are the forefront of the walk towards Allah SWT. Traces (Sirah) they are the best trip, their way most correct way. Morals they are the most spotless character (AlGhazali, 2017, p. 107). "From this work, it is understood that the Imam al-Ghazali put his admiration for Sufi teachings.

Imam al-Ghazali was so convinced of the Sufi acts as the right way, this is because for Imam al-Ghazali all motion and silence them, were born or their inner, plucked from the prophetic light. In addition to the prophetic light, there is no more light on the earth that can illuminate (Al-Ghazali, 2017, p. 107).

Ethics in the thought of Imam al-Ghazali oriented about "the consequences for the soul." In this case, Imam al-Ghazali saw the quality of the ethics depend on the impact for the soul. In life, there are certain goals. So if in the application of ethics increasingly benefiting the soul to reach its goal, then it is good. The purpose of studying ethics, generally divided into three important theories. First, learn just as purely theoretical studies without any intention to influence the behavior of that study. Secondly, studied with a view to changing attitudes and behavior and improve every day. Third, because ethics are theoretical subject, then in its investigation of the source of moral truth, there is always criticism of the required standard of morality that exists. In this case,

Ethics relating to the pursuit of happiness. But on the other hand, does not mean that ethics will lead to happiness exalt hedonism. Happiness or Sa'adah in understanding the Imam al-Ghazali is closely related to obedience to God by running the command and away from the ban. The foundations of the concept of ethics were initiated Imam alGhazali is the aqidah of tawhid and deeds with the limbs (Al-Ghazali, 2006, p. 10).

Ethic in the thinking of Imam al-Ghazali described as the rational science and religious science (Quasem, 1988, p. 16). However, it does not mean the dichotomy in the understanding of ethics as a science. Imam al-Ghazali did not put ethics as an option, whether as a rational science or theology. Ethics in the thought of Imam al-Ghazali covers the rational and religious matters. This is because Islam as a religion is very rational, as well as a rational science is acceptable in Islam.

Leadership must be able to accommodate between rational science and religious science. The separation between the two in ethics is a mistake that leads to danger. Even if leaders simply only choose one, it would result in chaos. It could be said that the rational science and religion science completed each other. Leaders who seek to 
understand the revelation as part of the religion science requires a sense as part of a rational science.

With aqidah as a foundation, Imam al-Ghazali emphasize the leaders in particular to take a certain time to be able to focus on worshiping God. It aims to cleanse the soul. He wrote advice to the leader as "What weighs if you specify one day in a special week for submissive to God for you, as well as if you have a slave and you ordered one day in a week specifically to serve you to be willing to provide such services although there were shortcomings in six days, then the slave against the (command) you .... when the slaves are not different from you as a servant of Allah (Al-Ghazali, 2006, p. 11).

Those that lead to the loss of others, is a sign he is not a believer and immoral. Here is emphasized that ethics is not just about themselves, regardless of others. To avoid actions harm others, then one must be fair. In order to be fair to others, one must do justice to himself (Quasem, 1988, p. 243). Imam Al-Ghazali for the world is the field for supplies hereafter. To ensure happiness in this world and the hereafter, need order and prosperity. Humans are the most wretched are those who fall for his kingdom and busy prosperity in the world, while he did not know how to live in the world so he crossed his world with difficulty and in the afterlife, he gained regret eternal and torment eternal (AlGhazali, 2006, p. 87).

Relating to political ethics, Al-Ghazali argued that man is a social creature. For that, he could not live alone. Furthermore, he sees there are two factors that cause why the man became a social being; first, the need for offspring for the survival of mankind and this can be done through intercourse between men and women and the family. Second, mutual help in providing food, clothing, and education of children (required cooperation and mutual help among humans) (Mubarok, 2008, p. 4).

Happiness in the hereafter can only be achieved by running kaffah religion. For that needed a leader and manager of the countries responsible for realizing the happiness in the world and in the hereafter. Based on that, the Imam Al-Ghazali, the obligation is an obligation Religion appointing leaders. Between the world and religion is closely inseparable bond that must be maintained by the leader and his people.

\section{The Concept of Leadership from The Perspective of Imam al-Ghazali}

Literally, siyasah closely related to leadership, command and prohibition, a leader of the people and settings to something that can bring benefit (Fida, 2017, p. 21). Imam Al-Ghazali argued that the power of (leadership), which regulates the political order of the world is very important for the world stability (nizam al-dunya) and the stability of the world is important for the religious order which will lead to happiness in the hereafter (Harris, 2016, p. 27-28). Religion in leadership becomes an important foundation for the purpose of happiness in the hereafter. The purpose of leadership supported by the ethics because for the Imam al-Ghazali, moral values should be supported by religious value. So that the existence of ethics in leadership is very important. To support the strong synergy of religion and the state, Imam al-Ghazali uses the development of knowledge, professionalism, and industrialization.

Religion is the subject of leadership. The leadership according to Imam AlGhazali also must be based on high moral integrity and benefit of the people. Leaders 
must understand the nature of power is a trust from God and to be accountable in the hereafter. Leadership is an effort to implement and administer Shari'a court-oriented world hereafter. Therefore, in al-Iqtishad fi al-I'tiqad, Imam al-Ghazali mention, "Religion is the basis and the sultan is the guardian..... the real aim of the sultan power is the need for world stability and compulsory world stability for the religious order and religious order needed for success in the hereafter.

Therefore, according to Imam al-Ghazali, there are several requirements for a person can be the leader of the country, namely :

1. Adults or Akil Baligh.

2. Having a healthy mind.

3. Independent.

4. Man.

5. Descendant of Quraish.

6. Having a healthy sense.

7. Has the real power.

8. Obtaining guidance (A Muslim).

9. Have the knowledge.

10. Wara' (able to control themselves and avoid adverse cases and doubtful).

The requirement to be a leader by Imam Al-Ghazali focuses on aspects of the character and integrity of a leader. But Imam Al-Ghazali does not impose a particular way in the election/appointment of leaders do not conflict with Islam. This requirement would not be separated from the living conditions of future Imam Al-Ghazali who at the time was full of political turmoil and thus require an intelligent and courageous leader (Sjadzali, 1990, p. 78).

Humans, in this case, need a good arrangement. therefore, the leadership is needed. The smallest setting at the beginning starts from lead yourself. This is like a hadith of the Prophet Muhammad which said :

"The Prophet Sallallaahu 'Alaihi Wasallam said, each of you is a leader, and each of you will be accountable for yourself. A husband is the leader of his family, and he will be accountable for them. A woman is the leader of the house of her husband, and he will be held accountable for it. And a slave is also a leader on top of the treasure of his master, and he also will be held accountable for it. Every one of you is a leader and each of you will be held accountable for it."

According to Imam al-Ghazali, the leader chosen to maintain order among humans and keep humanity from the oppression of other human beings. In order to guarantee the implementation of the mandate of this leadership, a leader is required to have a fair nature. With justice, then the leadership will avoid injustice, tyranny, and destruction. Justice, according to Imam al-Ghazali is "part of the perfection of reason, and the perfection of the reason is you believe in something, as the essence of something and do not be fooled by its outward forms (Al-Ghazali, 2006, p.37)." In another part of his work, Imam al-Ghazali wrote "The perfect justice consists of this: that you treat the unknown litigant of no repute and the well-known litigant of high worldly rank and 
dignity with complete impartiality in (your handling of) claims and disputes, viewing each with the same eye and not favoring one over the other. (Bagley, 1964, p. 69). "

Imam al-Ghazali prioritizes a spiritual bond (ukhuwah Islamiyyah) for unifying mankind. This spiritual bond should be treated by the leaders in order to avoid fragmentation and unity be maintained. Ethics have an important role in establishing a bond between people. However, it does not mean Imam al-Ghazali underestimate bond over countryman or bond over fellow human beings. Such ties are also important, it's just a spiritual bond is rated higher and at the same level with such kinship or marriage contract. The highest bonding levels will form the attitude of someone who put his brother than himself (Black, 2001, p. 198).

\section{Principles of Ethics in Leadership According to Imam Al-Ghazali}

Ethics in leadership are geared to its main objective, the happiness in this world and the hereafter. This goal is a lofty goal that has become human nature. The aim is also the measure of good and bad leadership. If the leadership produce increasingly influence the human soul closer to the main goal, then this is the ethics of good leadership. If the leadership of generating influence the human soul farther away or blocked from the main goal, then this is a bad leadership ethic.

In many of his works on politics and leadership, patterns of thought of Imam alGhazali is very thick with the feel of ethics. (Hasib, 2017, p. 5). Imam al-Ghazali thought laden ethics in leadership is mostly contained in his book Al-Masbuk Tibr Fii Nasihatii Al-Muluk authors summarized into 10 points, namely:

1. Sovereignty owned by the leader comes from God.

Imam Al-Ghazali understands that the leader is not absolute as God's representative because the source of sovereignty comes from God and served as a successor of the Prophet, as well as the concept of theocracy. Although Imam al-Ghazali in his book writes :

"Know and probably believe that God chose two groups among the descendants of Adam, namely the Prophets for His servants gave various explanations for the argument about the worship Him and how to know Him. He Choosing the authorities to keep the servants so as not to do wrong to one another "(Al-Ghazali, 2006: 69).

It did not become legal to allow the leader status muqaddas (holy) like a representative of God. What is the current Imam al-Ghazali stated that the leader is chosen by God, is to remind leaders that power is a trust/surrogate of God.

2. Always involve Ulama in leadership

The ulama is the best place for leaders to consult for advice. Very unethical for leaders who were never involved the ulama in leadership. The leader who ignored ulama is a mistake because he is not concerned with the good of religion. Ulama have a qualified knowledge to sustain leadership. Regarding law, ulama is reliable. Imam al-Ghazali stated, "The determination of the law and justice in the middle of guiding people with political action (siyasah), are entrusted to the fukaha (Black, 2001, p. 197)." The fukaha is a part of the ulama who understand the law. But that does not mean the leader can immediately believe all ulama, as well among them, there are ulama suu' (ulama with bad intention). 
3. Responsible for keeping its people to avoid sin

Good for a leader wouldn't just keep himself from sin or moral vileness, but he also had to keep away his people from it. the amanah is attached to a leader, not just to find enjoyment and safety of himself. Imam al-Ghazali wrote, "Should you (the leader) is not enough just to avoid your hands from sin, but also should take care of your followers, servants, and maid. Do not let them do injustice because you will be asked accountability for them, as you asked the accountability for the injustice of your own (Al-Ghazali, 2006, p. 36). "In its efforts to keep its people in order to avoid sin, the leaders must often help people, but he must also be careful not to help the wrongdoers.

4. Being able to control emotions and happy over criticism

This principle has been the foundation of modern government. Leaders should not be positioned to act authoritarian and must be always open himself to get criticisms. Emotion is fundamentally ingrained in human beings. But that does not mean every human being is free to release his emotions. But to eliminate the nature of these emotions, it's impossible. Because it's attached to our nature since we were born to this world. However, if uncontrolled, these properties will harm human beings.

You should know, anger cannot be eliminated entirely, but it can be reduced or controlled ... If someone aware that itself weakness and contemptible, surely he would not be arrogant and preserve his anger. Therefore, the anger will be made low and a shameful to release (Al-Ghazali, 2016, p. 399).

It would be very difficult to keep emotions for a bad ethical and not religious. Especially if he was faced with criticism from employees or citizens. Prophet Muhammad SAW. said, "The people are strong and bold it is a person who is able to defeat his anger, not to beat others (Badron, et al., 2016, p. 30)."

1. Treat people as he would like to be treated

According to Imam al-Ghazali, the leader is part of the people. Each policy that leaders have made, cannot be separated from the people. This is like the advice of Imam al-Ghazali, "This is that in every situation which arises, (the ruler) should figure that he is the subject and that the other person is the holder of authority; and that (he should not sanction for others) anything that he would not sanction for himself. (Bagley, 1964, p. 28-29). "

Even in a hadith Qudsi Allah says:

"O People, just as you hurt others, that's what you're going to be hurt. And, as you do, then like it was also you will be treated (Al-Ghazali, 2017b, p. 23). "This is an advice how leaders should be considering the impact of his actions. If he did not like something bad that other people do to him, then he should not do anything bad to someone else.

2. The leader is a servant of the people

In leadership, the fact is the leader has a duty to serve his people. So that must be understood for the leader that he should not just expect the service of the people. The ethics in leadership, leaders have not intended to be served, but to serve. People need a leader as a regulator and administrators for their affairs. This role should not be misunderstood by the leader. 


\section{Prioritizing simplicity}

Simplicity is the most important ethics in leadership. With simplicity, leadership will be spared a lot of harm. Imam al-Ghazali does not mean simplicity is poor and doesn't have anything. But the simplicity here is an option to be not too luxurious. Simplicity is also part of qana'ah. For Imam al-Ghazali, leaders are required to have an attitude of qana'ah (enough with that already exist), because without qana'ah, there will be no justice (Al-Ghazali, 2006, p. 44).

4. Leading by prioritizing the gentleness and friendliness

Treating people or subordinates with gentleness and friendliness is a very noble ethic. Imam al-Ghazali cites a hadith of the Prophet Muhammad about the virtues of being gentle as the ruler, "God have mercy on each ruler to exercise love and gentle with people and treat roughly every ruler who rude to people (Al-Ghazali, 2006, p. 45). "While the ethics of leadership taught to prioritize gentleness and friendliness, does not mean that a leader should not be firm. The requirement to be firm, especially in law enforcement should still be maintained. However, as long as it is still possible to be gentle and friendly, the leader should not be rude.

5. Trying to get the pleasure of the people with Islamic law

In an effort to implement ethics in leadership, people who support the role of the leader are needed. To be able to get help from the people, the people's pleasure is needed by leaders. Contentment here can be interpreted as caring or love of the people to the leaders. If people have loved the leader, it will appear contentment within themselves. In order to get the pleasure of the people, leaders should apply Islamic law as well as possible. Leaders, in this case, should be an example in implementing Islamic law. Efforts must be made so that the people's approval to the leader on condition of not violating the provisions of Islamic law.

6. God pleasure is the ultimate goal

Ethics in leadership should have a goal to be able to achieve happiness in this world and hereafter. Happiness in the hereafter, will not be achieved if it failed to gain the pleasure from Allah. So in order to achieve the main goal, a leader must prioritize to gain pleasure from Allah even though he was hated by others. Imam al-Ghazali wrote, Umar bin Khattab said. "Indeed, I became hated by most people." Every person deprived of some of his rights should feel hate and it is not possible he was willing for two opposite (Al-Ghazali, 2006, p. 46)."

\section{Conclusions}

Ethics in leadership should be the path for the application of God's law. Without good leadership, the law of God would be difficult to implement. So to be able to create a good leadership, it requires the adequate conception of ethics. Ethics in the thought of Imam al-Ghazali is a combination of theology and rational sciences. Good leadership must be backed by ethical containing the religious value. Leaders as those who gain the trust of leadership, should not ignore the ethical aspects as one measure of goodness. Ethics in leadership is not just about achieving goodness and human well-being in the world, but also in the hereafter. 
Proceeding ICOGISS 2019

Page :750-758. ISBN: 978-602-6 988-75-1

Web Jurnal Online: jurnal.unmuhjember.ac.id

By: Zahratul Idami; Andriansyah

The Concept of Ethics in Leadership According to Imam Al-ghazali Thought

\section{References}

Al-Ghazali, A.H. (2006). Nasihat Imam Al-Ghazali Bagi Para Penguasa. Translated by Safei. Bandung: Pustaka Setia. . (2016). Intisari Ihya' 'Ulumiddin. Translated by Ismaiel. Jakarta: Penerbit Qalam. . (2017). Pembebas Dari Kesesatan Bagaimana Kita Bisa Lepas dari Belenggu Kesesatan?. Translated by Kaserun. Jakarta: Turos Pustaka. . (2017). Intisari Hadits Qudsi. Translated by Kaserun. Jak Turos Pustaka.

Badron, M.S.., dan Saari, N.H. (2016). Kepimpinan dan Amanat Peradaban. Kuala Lumpur: Institut Kefahaman Islam Malaysia (IKIM).

Bagley, F.R.C. (1964). Ghazali Book of Counsel for Kings (Nasihat al-Muluk). London: Oxford University Press.

Black, A. (2001). Pemikiran Politik Islam: dari Masa Nabi Hingga Masa Kini. Translated by Abdullah Ali dan Mariana Ariestyawati. Jakarta: PT Serambi Ilmu semesta.

Fida, I.A. (2017). Ulama di Kancah Politik. Jurnal Pemikiran dan Peradaban Islam, Islamia, Volume XI, No. 1, February 2017, 19-27.

Harris, K.M.A. (2016). Ilmu Ketatanegaraan Melayu Raja Ali Haji: Thamarat AlMuhimmah \& Muqaddimah fi Intizam Waza'if Al-Malik. Dewan Bahasa dan Pustaka: Kuala Lumpur.

Hasib, K. (2017). Konsep Siyasah dan Adab Bernegara Menurut Imam Al-Ghazali. Jurnal Falasifa. Vol. 8 Nomor 1 March, 1-17.

Mubarok, H. (2008). Etika Politik dalam Pandangan Al-Ghazali (Kajian terhadap Kitab Al-Tibr al-Masbuk fii Nasihah al-Muluk). Skripsi. Yogyakarta: Universitas Islam Negeri Sunan Kalijaga.

Quasem, M.A. (1988). Etika Al-Ghazali Etika Majemuk Di Dalam Islam.Translated by J. Mahyudin. Bandung: Penerbit Pustaka.

Rahmat, P.S. (2009). Penelitian Kualitatif. Equilibrium. Vol. 5, No. 9, 1-8.

Sahri. (2013). Konsep Negara dan Pemerintahan dalam Perspektif Fikih Siyasah Al Gazzali. Jurnal Asy-Syir'ah. Volume 47, No. 2:519-560. Surabaya: UIN Sunan Ampel .

Sjadzali, M. (1990). Islam dan Tata Negara: Ajaran, Sejarah dan Pemikiran. Jakarta: Penerbit Universitas Indonesia. 